\title{
Pembelajaran Merdeka Pendidikan Arsitektur
}

\author{
Prasetyo Febriarto \\ Arsitektur, Sains dan Teknologi, Universitas Amikom Yogyakarta, \\ Jl. Ring Road Utara, Ngringin, Condongcatur, Kec. Depok, Kabupaten Sleman, DIY, \\ Email: arto1492@gmail.com
}

\begin{abstract}
Abstrak
Pandemi Covid-19 memunculkan berbagai upaya yaitu, himbauan untuk semua kegiatan di segala sektor mulai, ekonomi, pendidikan, hiburan, dan lain-lain dibatasi terutama di sektor pendidikan untuk mengurangi penularan Covid-19. Segala aktivitas pendidikan kegiatan akademik yang biasa dilakukan di kampus yaitu tatap muka, maka harus dilakukan dan dikerjakan dari rumah. Semua unsur akademik terutama pendidikan di tingkat kampus, tidak hanya mahasiswa, dosen dan tenaga pendidikan juga harus melakukan kegiatan dari rumah untuk mencegah dan mengurangi wabah Covid-19. Kebijakan dengan melihat fenomena pandemi yang mengakibatkan memaksa di sektor pendidikan mengubah pola kerja dan proses belajar mengajar harus melakukan terobosan atau inovasi yang awalnya dengan cara konvensional. Menggunakan terobosan yang merupakan usaha merdeka agar tetap berlangsung sesuai Tri Dharma Pendidikan dalam pembelajaran terutama di bidang arsitektur. Artikel ini dilakukan dengan metode penelitian deskriptif eksploratif untuk menjelaskan fenomena tentang pembelajaran merdeka pendidikan arsitektur.
\end{abstract}

Kata kunci: inovasi, pembelajaran merdeka, pendidikan arsitektur.

\begin{abstract}
Title: Freedom of Learning in Architecture Education

The Covid-19 pandemic has led to various efforts, namely, an appeal for all activities in all sectors, from the economy, education, entertainment, and others to be restricted, especially in the education sector to reduce the transmission of Covid-19. All educational activities, academic activities that are usually carried out on campus, namely face to face, must be done and done from home. All academic elements, especially education at the campus level, not only students, lecturers, and education personnel must also carry out activities from home to prevent and reduce the Covid-19 outbreak. Policies by looking at the pandemic phenomenon that has resulted in forcing the education sector to change work patterns and the teaching and learning process must make breakthroughs or innovations that were initially conventional. Using a breakthrough which is an independent effort to keep it going according to the tri dharma of education in learning, especially in the field of architecture. This article was conducted with a descriptive exploratory research method to explain the phenomenon of independent learning architecture education.
\end{abstract}

Keywords: innovation, independent learning, architectural education.

\section{Pendahuluan}

Melihat situasi dan kondisi saat ini yang mengharuskan berbagai kegiatan dilakukan di rumah, di antaranya adalah bekerja dari rumah, belajar dari rumah dan beribadah di rumah. Langkah tersebut sebagai upaya untuk mencegah penyebaran virus, memutus mata rantai penyebaran Covid-19. Working From Home (bekerja dari rumah) tentunya harus didukung dengan kebutuhan apa saja di 
lingkungan rumah. Pandemi Covid-19 memunculkan berbagai upaya, yaitu himbauan untuk semua kegiatan di segala sektor mulai, ekonomi, pendidikan, hiburan, dan lain-lain dibatasi, terutama di sektor pendidikan untuk mengurangi penularan Covid-19. Segala aktivitas pendidikan kegiatan akademik yang biasa dilakukan di kampus yaitu tatap muka harus dilakukan dan dikerjakan dari rumah. Semua unsur akademik terutama pendidikan di tingkat kampus, tidak hanya mahasiswa, dosen dan tenaga pendidikan juga harus melakukan kegiatan dari rumah untuk mencegah dan mengurangi penyebaran Covid-19. Kebijakan dengan melihat fenomena pandemi mengakibatkan sektor pendidikan terpaksa mengubah pola kerja dan proses belajar mengajar yang awalnya dengan cara konvensional harus melakukan terobosan atau inovasi. Menggunakan terobosan yang merupakan usaha merdeka agar tetap berlangsung sesuai Tri Dharma Pendidikan dalam pembelajaran terutama d ibidang arsitektur.

E-learning atau kuliah daring atau Pembelajaran Jarak Jauh (PJJ) sudah banyak diterapkan di banyak perguruan tinggi. Pemerintah Indonesia telah memberikan lampu hijau untuk pelaksanaan sistem ini dengan diterbitkannya Peraturan Menteri Pendidikan dan Kebudayaan No. 24 Tahun 2012 tentang Penyelenggaran Pendidikan Jarak Jauh Pada Pendidikan Tinggi. Seperti termuat dalam Peraturan Menteri tersebut, Pendidikan Jarak Jauh (PJJ) adalah pendidikan yang peserta didiknya terpisah dari pendidik dan pembelajarannya menggunakan berbagai sumber belajar melalui teknologi informasi dan komunikasi serta media lain (Faried et al., 2016).

Arsitektur adalah salah satu dari 16 sub sektor dalam industri kreatif di Indonesia. Peningkatan kualitas sumber daya manusia dalam bidang arsitektur idealnya diawali sejak duduk bangku kuliah. Universitas sebagai lembaga yang menaungi jurusan arsitektur bertanggung jawab terhadap sumber daya manusia di bidang arsitektur. Pembelajaran desain arsitektur sebagai mata kuliah utama pada jurusan arsitekur merupakan inti dari pembelajaran arsitektur. (Dewi \& Hayyun, 2018).

Dalam rangka menyiapkan mahasiswa menghadapi perubahan sosial, budaya, dunia kerja dan kemajuan teknologi yang pesat, kompetensi mahasiswa harus disiapkan untuk lebih gayut dengan kebutuhan zaman. Link and match tidak saja dengan dunia industri dan dunia kerja tetapi juga dengan masa depan yang berubah dengan cepat. Perguruan Tinggi dituntut untuk dapat merancang dan melaksanakan proses pembelajaran yang inovatif agar mahasiswa dapat meraih capaian pembelajaran mencakup aspek sikap, pengetahuan, dan keterampilan secara optimal dan selalu relevan. Kebijakan Merdeka Belajar - Kampus Merdeka diharapkan dapat menjadi jawaban atas tuntutan tersebut. Kampus Merdeka merupakan wujud pembelajaran di perguruan tinggi yang otonom dan fleksibel sehingga tercipta kultur belajar yang inovatif, tidak mengekang, dan sesuai dengan kebutuhan mahasiswa. (Buku-Panduan Merdeka Belajar Kampus Merdeka 2020) 


\section{Metode}

Menggunakan deskriptif eksploratif untuk menjelaskan fenomena tentang pembelajaran merdeka pendidikan arsitektur.

\section{Hasil dan Pembahasan}

Melalui Surat Edaran Mendikbud RI No 3 Tahun 2020 tentang Pencegahan Covid-19 pada satuan Pendidikan, melalui Surat Edaran Mendikbud RI No 3549/A.A5/HK/2020 tentang pencegahan penyebaran Corona Virus Disease (COVID 19), melalui Keputusan Kepala Badan Nasional Penanggulangan Bencana (BNPB) Tentang Perpanjangan Status Keadaan Tertentu Darurat Bencana Wabah Penyakit Akibat Virus Corona di Indonesia dan melalui Keputusan Gubernur Daerah Istimewa Yogyakarta Nomor 65/KEP/2020 Tentang Penetapan Status Tanggap Darurat Bencana Corona Virus Disease 2019 (Covid19) di Daerah Istimewa Yogyakarta, tidak terkecuali Universitas AMIKOM Yogyakarta mengambil langkah tegas dengan himbauan pemerintah untuk melakukan aktivitas belajar dari rumah. Pelaksanaan perkuliahan di Universitas AMIKOM Yogyakarta dimulainya perkuliahan semester genap 2019-2020 pada Senin, 2 Maret 2020 dan juga masuknya pertama wabah Covid-19 di Indonesia. Pelaksanaan pada dua minggu perkuliahan tetap berjalan dan wabah Covid-19 mulai meluas. Maret pada awal minggu ke kegiatan perkuliahan secara tatap muka ditiadakan sehingga mahasiswa tidak masuk kuliah, tenaga pendidik pun juga diliburkan. Minggu ketiga terjadi kebingungan bagaimana caranya kegiatan pembelajaran harus tetap dilaksanakan. Kemudian kegiatan rapat tenaga pendidikan mulai menggunakan daring (online) untuk memutuskan bagaimana seharusnya. Pada minggu keempat dari pihak universitas melalui Surat Keputusan Rektor dengan dasar pertimbangan surat keputusan dari kementrian terkait, badan terkait, dari pemerintah daerah maka mengambil langkah tegas atas himbauan pemerintah untuk melakukan aktivitas belajar dari rumah. Aktivitas belajar dari rumah diberlakukan tidak hanya untuk kalangan mahasiswa, tidak luput pula dari dosen dan tendik (tenaga pendidikan) untuk pencegahan wabah Covid-19. Kebijakan dan fenomena pandemi yang terjadi memberikan dampak yang luar biasa, merembet cepat dan meluas keadaan dalam darurat sehingga memaksa sektor pendidikan tinggi merubah, mengganti pola kerja pelayanan, kegiatan pembelajaran dari konvensional menjadi berbasis daring (online). Dalam pelaksanaan pembelajaran di tengah pandemi Covid-19, para dosen dihadapkan dengan keadaan kuliah yang berbeda. Para dosen harus segera menyesuaikan metode dengan menggunakan pembelajaran sistem daring (online). Pendidikan arsitektur yang terkait dengan teori dan praktik rekayasa rancang bangun di perguruan tinggi dalam pelaksanaan seperti biasa berupa kuliah tatap muka, kini dalam masa darurat bencana Covid-19 memberlakukan metode pembelajaran full daring (online) atau berbasis e-learning untuk seluruh mata kuliah dengan perantara perangkat teknologi informasi yang pada setiap mata kuliah diampu oleh masing-masing dosen mata kuliah tersebut. Mahasiswa dapat mengakses materi perkuliahan, untuk berdiskusi, presentasi tugas-tugas, serta mengakses tugas kuliah yang diberikan dosen. 
Pada kondisi darurat dalam metode Pembelajaran Merdeka, dosen diberi kewenangan dalam melaksanakan perkuliahan secara daring dan isi materi kuliah disesuaikan dengan kondisi mahasiswa yang berkaitan dengan penugasan. Dalam hal ini dosen harus mengerti kebutuhan saat pandemi karena terdapat mahasiswa perantauan yang pulang kampung, meskipun begitu tetap masih ada mahasiswa perantauan yang tidak pulang kampung dan kuliah dari rumah. Selama satu semester jika mahasiswa hanya kuliah di rumah saja dengan diberi tugas yang banyak maka dapat muncul kebosanan karena di rumah saja hanya mengerjakan tugas dan kuliah terus menerus sehingga dapat mempengaruhi kesehatan. Dosen diberi kewenangan untuk tidak memberi banyak tugas pada mata kuliah arsitektur yang bersifat teori. Dosen juga diberi kewenangan menyederhanakan materi kuliah yang berbeda dengan yang ada pada Rencana Pembelajaran Semester (RPS) karena sudah melalui konsultasi dengan pimpinan untuk mata kuliah yang bersifat praktik. Meskipun begitu tetap harus melihat dahulu seberapa jauh yang harus diubah karena dalam keadaan darurat jika dipaksakan sesuai RPS maka mahasiswa tidak akan menangkap materi. Alasan tidak dapat menangkap materi adalah karena materi kuliah yang bersifat praktik. Para dosen sebaiknya sudah memperkirakan bahwa jika materi praktik tetap diajarkan secara daring (online) kemungkinan akan tidak berhasil dengan melihat situasi kondisi perangkat elektronik yang dimiliki mahasiswa kurang mendukung (laptop, $P C$, software). Maka seyogyanya materi kuliah tidak memberatkan mahasiswa dan dosen juga secepatnya memetakan situasi kondisi mahasiswa dan suasana perkuliahan.

Para dosen dipacu untuk berinovasi sehingga dapat lebih cepat dan kreatif dalam memberikan materi pembelajaran secara online yakni seperti materi kuliah yang sifatnya praktik dengan membuat bentuk dua dan tiga dimensi maka dosen dengan membuat video pembelajaran dalam bentuk tutorial yang diunggah di YouTube atau perekaman materi video kemudian diunggah di Google Classroom. Selanjutnya, setiap pertemuan ada konsultasi dan diskusi dengan menggunakan Whatsapp Group. Materi kuliah yang sifatnya teori, dosen merekam materi dengan perangkat rekam yaitu OBS Studio kemudian pemberian tugas dapat diunggah di Google Classroom dan diskusi dapat dilakukan dengan menggunakan Whatsapp Group. Sedangkan untuk mata kuliah yang bersifat praktik seperti Studio Perancangan Arsitektur, dosen dapat merekam materi dengan perangkat rekam yaitu OBS Studio kemudian pemberian tugas dapat diunggah di Google Classroom dan diskusi dengan menggunakan Whatsapp Group atau menggunakan aplikasi video conference seperti Zoom atau Google Meet. Pembelajaran di mata kuliah Studio Perancangan Arsitektur sangat terkait dengan pemilihan site (tapak), sehingga materi tentang site yang harus diberikan kepada mahasiswa dalam pelaksanaannya terdapat perbedaan dan tantangan di masa pandemi ini. Perbedaannya pada keadaan normal terdapat pembagian kelompok dan pada pademi tidak ada pembagian kelompok, dapat diganti secara individu dengan pemilihan site yang dibebaskan dengan tetap memberikan kriteria-kriteria tapak (site) dari dosen pembimbing.

Memanfaatkan perangkat pembelajaran berbasis e-learning tersebut dosen harus tetap memperhatikan perkembangan mahasiswa yakni dengan memastikan hak memperoleh pendidikan tetap berjalan meskipun dengan perantara 
teknologi. Presensi pun juga dilakukan secara online baik untuk dosen maupun mahasiswa. Dosen melakukan presensi kerja dengan menggunakan aplikasi Google Form yang terhubung dengan server universitas, sedangkan mahasiswa melakukan presensi dengan menggunakan presensi online yang telah disediakan karena digunakan untuk penilaian akhir. Kunci dari semuanya itu adalah tetap menjalin komunikasi. Penggunaan teknologi dan pelaksanaan sistem pembelajaran daring (online) di masa pandemi Covid-19 ini tentunya memiliki sisi positif dan negatif. Sisi positif dari pembelajaran daring salah satunya membuka kebebasan ekspresi dari ide-ide mahasiswa yang tidak muncul ketika perkuliahan tatap muka karena rasa malu, segan, takut atau bahkan belum memiliki kemampuan verbal yang baik. Selain itu, pembelajaran daring juga dapat membantu mahasiswa yang tinggal di daerah terpencil yang kesulitan akses menuju kampus maupun berbenturan waktu terutama mahasiswa yang kuliah sambil bekerja. Pembelajaran daring juga dapat meningkatkan kreativitas dan kemandirian pada dosen maupun mahasiswa dalam memperkaya dirinya dengan terus berinovasi untuk selalu mencari pengetahuan baru. Dosen dan mahasiswa sama-sama harus menguasai teknologi. Sisi negatif dari pembelajaran daring (online) adalah berbedanya tingkat kepahaman antar mahasiswa dalam belajar daring. Mahasiswa yang rajin dapat dengan mudah menyerap informasi dan materi perkuliahan. Namun bagi mahasiswa yang kurang terbiasa dengan belajar daring kemungkinan akan kesulitan dalam menyerap materi dari dosen dan juga kesulitan beradaptasi dengan penggunaan aplikasi teknologi sebagai perantara kegiatan pembelajaran (https://republika.co.id/berita/q8gkaa374/covid19-danpotret-pembelajaran-berbasis-elearning, diakses 8 April 2020). Perkuliahan dari rumah juga menjadi kendala serius khususnya bagi mahasiswa yang kurang mampu secara ekonomi terkait penggunaan kuota internet. Jaringan internet yang kurang stabil juga menjadi kendala bagi mahasiswa yang bertempat tinggal di daerah pedalaman.

Penyesuaian Pembelajaran Menuju Kampus Merdeka yang utama adalah pada bentuk kegiatan pembelajaran seperti di bawah ini (Gambar 1) menurut Buku Panduan Merdeka Belajar Kampus Merdeka 2020, Direktorat Jenderal Pendidikan Tinggi Kementerian Pendidikan dan Kebudayaan 2020.

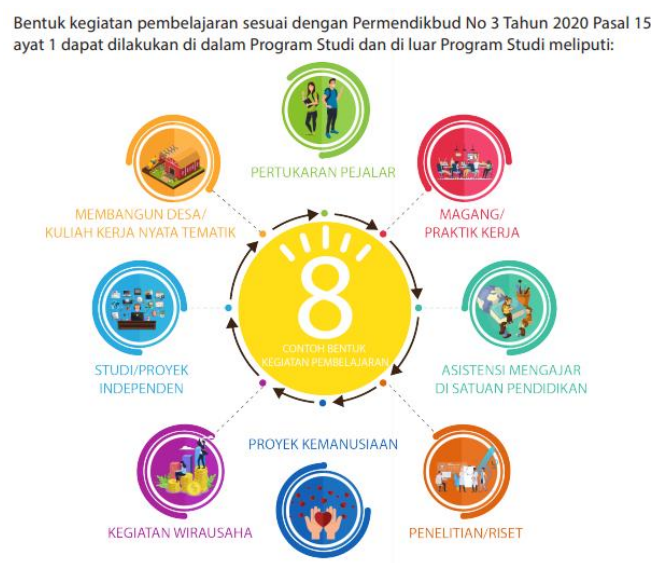

Gambar 1. Bentuk kegiatan pembelajaran sesuai dengan Permendikbud Nomor 3 Tahun 2020 Pasal 15 Ayat 1

Sumber: Direktorat Jenderal Pendidikan Tinggi Kementerian Pendidikan dan Kebudayaan, 2020 
Program Studi Arsitektur, Fakultas Sains dan Teknologi, Universitas Amikom Yogyakarta sudah menerapkan Kampus Merdeka meskipun masih sebagian kecil seperti dalam masa pandemi Covid-19 ini yaitu dalam pelaksanaan magang atau praktik kerja. Pada masa kondisi normal, pelaksanaan magang atau praktik kerja mahasiswa di konsultan perencana arsitektur atau di kontraktor bangunan, dengan adanya pandemi maka prodi memberikan alternatif selain magang atau praktik kerja yaitu kegiatan penelitian untuk mahasiswa namun tetap dengan bimbingan oleh dosen. Harapannya, melalui penelitian tersebut mahasiswa dapat membangun cara berpikir kritis sehingga mahasiswa akan lebih mendalami, memahami dan mampu melakukan metode penelitian yang lebih baik.

\section{Kesimpulan}

\section{Pembelajaran Merdeka}

1. Sektor pendidikan menghadapi dilema sistem pembelajaran dari tradisional menjadi digital.

2. Membuat terobosan baru, dengan memanfaatkan teknologi dalam pelaksanaan pembelajaran pendidikan.

3. Memaksa berinovasi dan berkreasi menggunakan teknologi. Menjalani di tengah sesuatu yang tidak biasa yang harus dihadapi

4. Siap atau tidak siap harus bekerja keras, berpikir kreatif, berinovasi dan beradaptasi dengan mengubah model kegiatan pembelajaran berbasis daring (online) atau e-learning.

5. Dosen dan mahasiswa harus meningkatkan kreativitas dan mandiri dalam memperkaya kemampuan. Harus berinovasi untuk selalu mencari pengetahuan dan pengalaman baru.

\section{Pembelajaran Menuju Kampus Merdeka}

1. Konsep tersebut baik karena memiliki banyak pilihan demi mendukung meningkatkan kreativitas dan kemandirian serta membuat mahasiswa untuk selalu berinovasi demi mencari pengetahuan baru.

2. Institusi pendidikan yakni Perguruan Tinggi Menuju Kampus Merdeka perlu persiapan yang matang.

\section{Daftar Pustaka}

Direktorat Jenderal Pendidikan Tinggi Kementerian Pendidikan dan Kebudayaan. (2020). Buku panduan merdeka belajar kampus merdeka 2020. Jakarta: Direktorat Jenderal Pendidikan Tinggi Kemdikbud RI.

Dewi, H.I. \& Hayyun, M. (2018). Alternatif metode kreatif untuk pembelajaran disain arsitektur menghadapi era 4.0. IKRAITH-HUMANIORA, 2(3), 7-11.

Faried, M.I., Istiyowati, L.S., Atmodjo D. (2016). Model pembelajaran e-learning untuk menunjang pembelajaran dengan kurikulum yang berbasis KBK. Jurnal TICOM, 4(3), 72-90.

Kementrian Pendidikan dan Kebudayaan RI. (2012). Peraturan Menteri Pendidikan dan Kebudayaan Republik Indonesia no. 24 tahun 2012 tentang 
penyelenggaraan Pendidikan jarak jauh pada pendidikan tinggi. Jakarta: Kementrian Pendidikan dan Kebudayaan RI.

Kementrian Pendidikan dan Kebudayaan RI. (2020). Surat edaran no. 3 tahun 2020 tentang pencegahan Corona Virus Desease (COVID-19) pada satuan pendidikan. Jakarta: Kementrian Pendidikan dan Kebudayaan RI.

Gubernur Daerah Istimewa Yogyakarta. (2020). Keputusan Gubernur Daerah Istimewa Yogyakarta nomor 65/KEP/2020 tentang penetapan status tanggap darurat bencana Corona Virus Desease (COVID-19) di Daerah Istimewa Yogyakarta. Yogyakarta: Gubernur Daerah Istimewa Yogyakarta. 